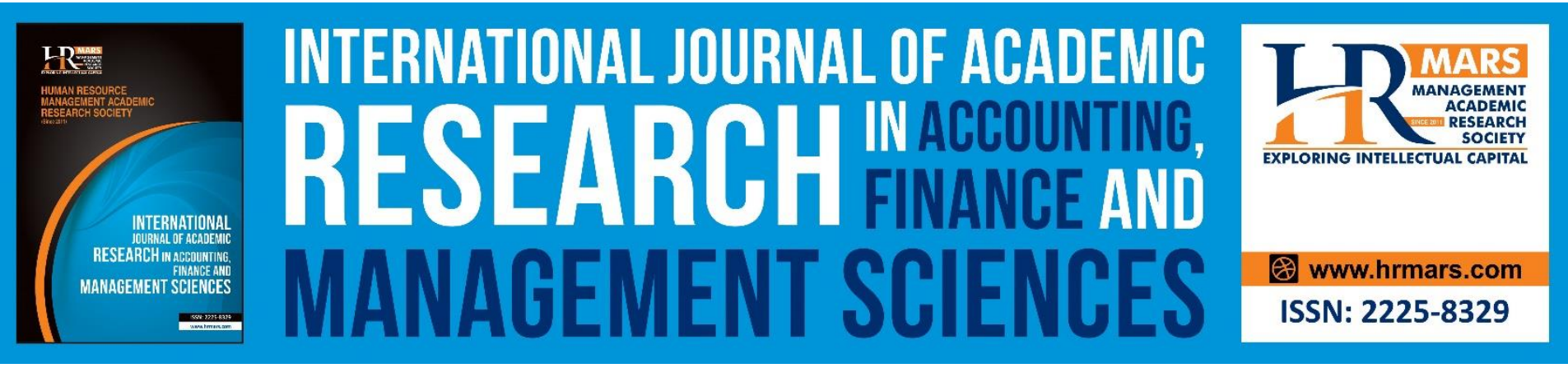

\title{
Earning Management: Analysis of Non-Banking Firms Listed in Nairobi Securities Exchange using Beneish M-Score and Altman Z-Score.
}

\section{Samuel Ngigi Nyakarimi}

To Link this Article: http://dx.doi.org/10.6007/IJARAFMS/v11-i1/8407

DOI:10.6007/IJARAFMS /v11-i1/8407

Received: 23 December 2020, Revised: 21 January 2021, Accepted: 09 February 2021

Published Online: 26 February 2021

In-Text Citation: (Nyakarimi, 2021)

To Cite this Article: Nyakarimi, S. N. (2021). Earning Management: Analysis of Non-Banking Firms Listed in Nairobi Securities Exchange using Beneish M-Score and Altman Z-Score. International Journal of Academic Research in Business and Social Sciences, 11(1), 80-90.

\section{Copyright: (c) 2021 The Author(s)}

Published by Human Resource Management Academic Research Society (www.hrmars.com)

This article is published under the Creative Commons Attribution (CC BY 4.0) license. Anyone may reproduce, distribute, translate and create derivative works of this article (for both commercial and non-commercial purposes), subject to full attribution to the original publication and authors. The full terms of this license may be seen at: http://creativecommons.org/licences/by/4.0/legalcode

$$
\text { Vol. 11, No. 1, 2021, Pg. } 80 \text { - } 90
$$

Full Terms \& Conditions of access and use can be found at http://hrmars.com/index.php/pages/detail/publication-ethics 


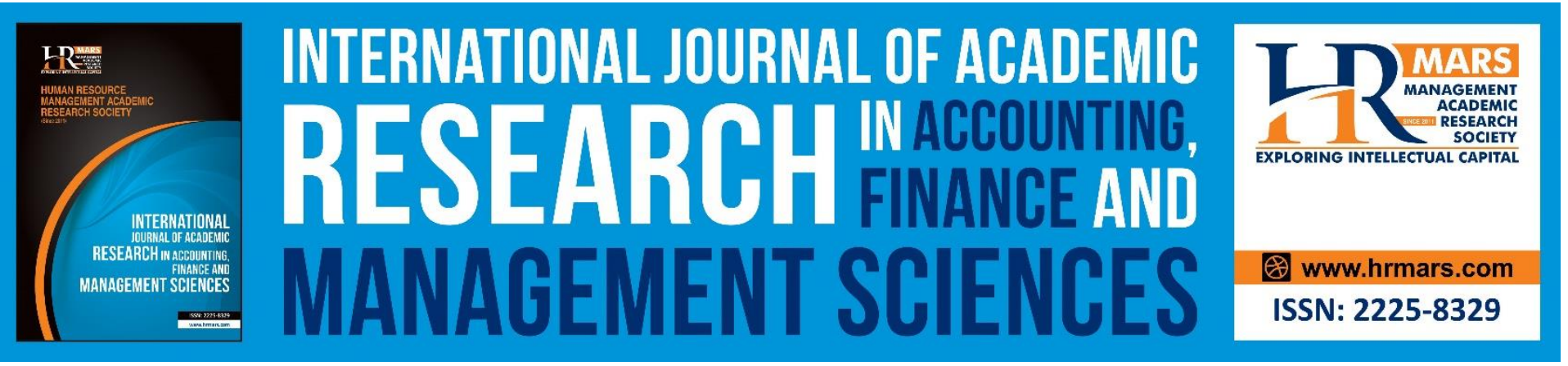

\title{
Earning Management: Analysis of Non-Banking Firms Listed in Nairobi Securities Exchange using Beneish M-Score and Altman Z-Score.
}

\author{
Samuel Ngigi Nyakarimi \\ University of Embu \\ Email: samnngigi@yahoo.com
}

\begin{abstract}
Earning management or manipulation has been that has been used for a long time by the management of various firms to adjust financial reports to meet certain objectives. This practice has been used even for fraudulent and selfish activities. The purposes of the research were to ascertain the levels of earning manipulations and financial distress of non-banking firms listed in Nairobi securities exchange. The latest financial statements were used as the source of information. The Beneish five-variable model was used to determine the presence of earning manipulations. Altman's Z-Score was used to test the financial distress. The analysis revealed that $58.3 \%$ of the firms were not involved in earning manipulations. Further data showed that $41.7 \%$ of the analysed firms were in financial distress. The study recommends restitutions by fraud perpetrators through earning manipulations, change of auditors approach to certification of financial reports by including ratios calculations and financial bailout by the government and owners of the businesses in case of financial distress based on economic hardships.
\end{abstract}

Keywords: Earing Management, Beneish Model, Altman Z-Score

\section{Introduction}

The levels of fraud, unethical behaviour and financial statement manipulations in corporations have increased at great level in the world in recent period (Mahama, 2015). The management of the firm have used earning management as a strategy of deliberately manipulating financial statements. Earning management is applied to achieve a predetermined financial targets to stabilize the reported financial levels thus not reporting too high or too low earnings (Iraya et al., 2015). Earning management is connected to deliberate manipulation of financial records to fulfil sum predetermined and definite aims. Financial statement manipulations are motivated by the management's desire to present rosy financial statements to the shareholders that shows the financial targets of the firms have been met. The practice is amplified by information asymmetry as the management have control 
INTERNATIONAL JOURNAL OF ACADEMIC RESEARCH IN ACCOUNTING, FINANCE AND

MANAGEMENT SCIENCES

Vol. 11, No. 1, 2021, E-ISSN: 2225-8329 @ 2021 HRMARS

of financial reporting and access to financial statements that they can use to change the reports and obtain desirable reporting (Abbadi et al., 2016)

Earning management as a practice occurs when the managers interfere with financial statements preparations in order to hoodwink the stockowners on the financial position of the firm. The managers may also engage in earning management due to personal benefits. The practice may also be used to leverage the firm against poor credit rating to avoid violations of agreements in lending like debt to equity ratio (Haque et al., 2016). The aim of earning management on debt issues is mainly to benefit from cheap form of capital (Nikoomaram et al., 2016). There are several motivational factors that push management to practice earning management. The motivational factor may include and not limited to; political, bonus payment, tax reduction, reputational reasons, stock and share public offer and debt induced factors (Muda et al., 2018)

In practice earning management is practiced by both large and smaller firms. The investors may lead the managers of large to practice earning management due to high expectations. Though large are engaged in earning management they consider the cost as well as their reputation thus this practice is less prevalent in large firms as compared to large firms (Ali et al., 2015). Earnings management affects the organization's future performances and prospects as the management is willing to boost the current financial period's income by foregoing the immediate future cash flows (Ismail et al., 2015). When earning management is practiced without considering the accounting principles it becomes illegal thus becomes fraud. This practice hinders the rationality of investors in making investing decisions (Ahmed \& Naima, 2016).

\section{Objective of the Study}

The purpose of the study was;

1) To establish whether non-banking firms listed in Nairobi Securities Exchange are engaged in earning management.

2) To determine financial soundness of the non-banking firms listed in Nairobi Securities Exchange.

\section{Research Questions}

1) Do non-banking firms listed in Nairobi Securities Exchange engage in earning management?

2) Are non-banking firms listed in Nairobi Securities Exchange financially sound?

\section{Literature Review}

Various studies on earning management have been undertaken in various countries, in different economic sectors and have shown different results. Muda et al. (2018) carried out research on effect of corporate governance on earning management in Indonesian manufacturing sector. The results showed that the audit committee and board of commissioners did not have any effect on earning management. Study on manipulation of earnings in various sectors in Italy by Paolone and Magazzino (2014) found that the food industry had the highest probability of financial statement manipulation followed by metallurgic Industry. The clothing industry had the highest probability of manipulation whereas the probability of manipulations for both automotive and textile were somewhat moderate. The study on earning manipulation in Bangladesh by Ahmed and Naima (2016) it was concluded that there was decline in manipulation of behaviour among non-banking firms in Bangladesh. Shahzad (2016) studied the earning management and earning manipulations in BRIC countries, the study 
INTERNATIONAL JOURNAL OF ACADEMIC RESEARCH IN ACCOUNTING, FINANCE AND MANAGEMENT SCIENCES

Vol. 11, No. 1, 2021, E-ISSN: 2225-8329 @ 2021 HRMARS

concluded that Brazilian and Indian firms had weak corporate governance and were involved in earning manipulations. The model applied could not detect rampart earning manipulation in Russian firms as the data from these was limited. The Chinese companies were involved in earning manipulations as the firms do not follow the International Accounting Standards or Generally Acceptable Accounting Practices. There has been established that there is connection between the switching of auditors and earning manipulation as per the conclusion of the study on Malaysian firms by Ismail et al. (2015).

The capital structure has been found to have a negative effect on earning management as per the conclusion of the study undertaken by Nikoomaram et al. (2016) on the relationship between capital structure and earning management. The quality of corporate governance has a negative effect on earning management as per the study on Jordanian firms by Abbadi et al. (2016). Ali et al. (2015) undertook a study to establish the impact of firm's size on earning management in Pakistan, the study concluded that there was positive connection between the firm's size and earning management due to undue pressure from the investors and financial analysts to present favourable earnings. The study by Lu (2017) found that $73.9 \%$ of all sampled companies were involved in earning management by inflating their incomes. The quality of audit has been found to have a positive and significant effect on earning management as per the study by Sari and Sari (2019) undertaken in Indonesia.

\section{Methodology}

The study applied content analysis as data collection method where the latest audited accounts of all non-banking firms listed in Nairobi Securities Exchange were analysed. The data was analysed for any financial statement manipulations using Beneish five-variable model and Altman Z-score model was used to assess any financial distress signs among the non-banking firms listed in Nairobi securities exchange.

\section{Beneish Model}

Beneish M-Score is applied in analysis of financial statements using ratios to detect the fraudulent manipulations. The model though cannot be completely accurate (Tarjo \& Herawati, 2015). Beneish model is of two versions; an eight-variable and five-variable model. Roxas (2011) indicated that the five-variable Beneish model was more accurate in determining the manipulators. The M-Score of less or equal to -2.76 indicates that the firm under analysis could be engaged in fraudulent manipulation of financial statements (Feruleva \& Maria, 2017). Therefore this study utilised the five-variable model to reflect an accurate picture on the financial statements manipulation. In Beneish five-variable model any firm with an M-Score of

The model that was applied is as follows;

$$
\begin{aligned}
& \mathrm{M}=-6.065 \text { + 0.823 DSRI + 0.906 GMI + 0.593 AQI + 0.717 SGI + 0.107 DEPI } \\
& \text { Where: Day Sales in Receivable Index }(\text { DSRI })=\frac{\text { Net Receivables } n / \text { Sales } n}{\text { Net Receivables } n-1 / \text { Sales } n-1} \\
& \text { Gross Margin Index (GMI) }=\frac{\text { Sales } n-1-\text { Cost of Sales } n-1 / \text { Sales } n-1}{\text { Sales } n-\text { Cost of Goods } n / \text { Sales } n} \\
& \text { Asset Quality Index }(A Q I)=\frac{1-(\text { Current Asset } n+P P E ~ n) / \text { Total Assets } n}{1-(\text { Current Asset } n-1+\text { PPE } n-1) / \text { Total Assets } n-1} \\
& \text { Sales Growth Index (SGI) }=\frac{\text { Sales } n}{\text { Sales } n-1} \\
& \text { Depreciation Index }(\text { DEPI })=\frac{\text { Depreciation } n-1 /(\text { Depreciation } n-1+P P E n-1)}{\text { Depreciation } n /(\text { Depreciation } n+P P E n)}
\end{aligned}
$$




\section{Altman Z-Score}

The Z-Score is mainly applied in predicting financial distress and bankruptcy (Altman et al., 2010). The Z-Score measures all aspects of corporate performance which improves reliability and conclusions besides eliminating bias (Mahama, 2015). The M-Score and Z-Score are similar though the M-Score concentrates on earning management and Z-Score concentrates on predicting bankruptcy (Omar et al., 2014). The Z-Score has been used in various studies to establish the existence financial statement frauds (Mehta \& Bhavani, 2017). The study applied this model to try and establish the existence of financial distress of all non-banking firms listed in Nairobi Securities Exchange. The Z-Score parameters indicate that; any Z-Score of above 2.99 the firm is financial stable, a Z-Score of between 2.77 and 2.99 requires the management or shareholders to be cautious, a Z-Score of between 1.88 and 2.77 indicates that the firm is likely to be bankrupt within two years whereas ant Z-Score of below 1.88 indicates a very high likelihood of bankruptcy (Mehta \& Bhavani, 2017). However, Mavengere (2015) restated the threshold of Altman's Z-Score as follows; the Z-Score which is greater than 2.67 indicates financial soundness, a Z-Score of between 1.81 and 2.67 was categorised as a grey area meaning that the firm may fall into financial distress or recover to financial soundness and finally the firms with Z-Score of less than 1.81 was categorised as financial distressed firm. The following model was applied;

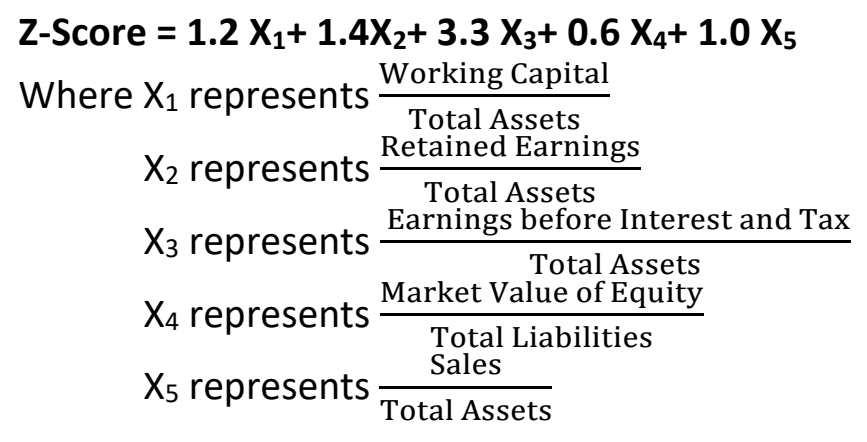

\section{Data Analysis and Results}

The study's first objective was to determine whether non-banking firms listed in Nairobi securities exchange were involved in earning management or earning manipulation. To meet the objective Beneish five-model variable was applied. According to Raxis (2011), the value of $m$-score under Beneish five-variable model, should be less or equal to -2.76 for a firm to be categorised as nonmanipulator. The results of the analysed firms are presented in table 1 . In the analysis the firms that were not involved in earning manipulations were coded as 0 and those firms that have been found to be involved in earning manipulations were coded as 1 The results obtained and presented in table 1 show that about $58.3 \%$ of the analysed firms were categorised as non-manipulators. This means that $41.7 \%$ of the firms analysed were involved in earning manipulations. 
INTERNATIONAL JOURNAL OF ACADEMIC RESEARCH IN ACCOUNTING, FINANCE AND MANAGEMENT SCIENCES

Vol. 11, No. 1, 2021, E-ISSN: 2225-8329 @ 2021 HRMARS

Table 1: Beneish M-Score Results for Manipulators or Non-Manipulators

\begin{tabular}{|c|c|c|c|c|c|c|c|}
\hline & DSRI & GMI & $A Q I$ & SGI & DEPI & M-SCORE & Code \\
\hline 1 & 5.3688 & -0.4225 & 0.2707 & 1 & 1.038 & -1.04067 & 1 \\
\hline 2 & 1.2821 & 0.8448 & 1.0881 & 1.3411 & 0.8003 & -2.552 & 1 \\
\hline 3 & 2.0805 & 0.7494 & 1.117 & 0.8738 & 1.2343 & -2.25283 & 1 \\
\hline 4 & 0.7139 & 0.5997 & 0.7854 & 1.1781 & 0.8987 & -3.52753 & 0 \\
\hline 5 & 0.4872 & 0.6532 & 0.4665 & 0.7575 & 1.0362 & -4.1416 & 0 \\
\hline 6 & 0.2809 & 0.9701 & 1.5726 & 0.9162 & 0.9984 & -3.25861 & 0 \\
\hline 7 & 1.088 & -1.0723 & 1.2762 & 0.8371 & 0.9341 & -4.68414 & 0 \\
\hline 8 & 0.0442 & 1.4121 & 0.7968 & 0.9182 & 1.2742 & -3.48207 & 0 \\
\hline 9 & 0.5424 & 0.0061 & 1.0119 & 0.4716 & 0.9769 & -4.57036 & 0 \\
\hline 10 & 5.123 & -31.4096 & 234.5 & 0.7664 & 0.1568 & 109.3189 & 1 \\
\hline 11 & 0.9448 & 0.9993 & 6.012 & 1.0872 & 1.0542 & 0.075374 & 1 \\
\hline 12 & 1.6868 & 0.8246 & 1.1186 & 0.9594 & 1.0935 & -2.46145 & 1 \\
\hline 13 & 1.6214 & -1.5802 & 0.9983 & 0.8552 & 0.346 & -4.92006 & 0 \\
\hline 14 & 0.7341 & 1.1389 & 1.5026 & 0.8977 & 0.9589 & -2.7917 & 0 \\
\hline 15 & 1.0877 & 1.0268 & 1.1769 & 0.9107 & 0.9641 & -2.78551 & 0 \\
\hline 16 & 1.3918 & 0.9461 & 1.2003 & 0.8985 & 1.339 & -2.56311 & 1 \\
\hline 17 & 0.8505 & 1.018 & 0.4149 & 1.0149 & 1.0328 & -3.3585 & 0 \\
\hline 18 & 0.1634 & 1 & 1.2247 & 5.4347 & 0.2948 & -0.37005 & 1 \\
\hline 19 & 0.1001 & 1 & 1.0822 & 1.207 & 1.2055 & -3.44047 & 0 \\
\hline 20 & 0.6199 & 1.2984 & 1.0172 & 1.0887 & 1.1575 & -2.87082 & 0 \\
\hline 21 & 1.5383 & 1 & 1.1255 & 0.6414 & 1.1243 & -2.64537 & 1 \\
\hline 22 & 0.8793 & 1.1639 & 0.9103 & 1.1898 & 0 & -2.89395 & 0 \\
\hline 23 & 0.8956 & 0.9602 & 0.8507 & 1.0535 & 0.973 & -3.09404 & 0 \\
\hline 24 & 0.7559 & 1.1255 & 0.8129 & 1.0184 & 0.8836 & -3.1164 & 0 \\
\hline 25 & 1.5072 & 1 & 1.2034 & 0.9061 & 0.7395 & -2.47616 & 1 \\
\hline 26 & 0.7786 & 1.1139 & 0.8935 & 0.9867 & 0.9392 & -3.07722 & 0 \\
\hline 27 & 0.6207 & 1.0889 & 1 & 1.0913 & 0.9572 & -3.08974 & 0 \\
\hline 28 & 1.136 & 1 & 1.0013 & 1.0831 & 0.9467 & -2.75242 & 1 \\
\hline 29 & 0 & 1 & 0.9845 & 0.8976 & 0.3333 & -3.89595 & 0 \\
\hline 30 & 1.0548 & 0.891 & 0.811 & 1.0118 & 1.1212 & -3.0633 & 0 \\
\hline 31 & 1.334 & 1.171 & 1.3194 & 0.8956 & 1.1603 & -2.35749 & 1 \\
\hline 32 & 1.0179 & 0.9854 & 1.8051 & 1.0478 & 1.0706 & -2.39824 & 1 \\
\hline 33 & 1.4252 & 1 & 1.0081 & 1.0651 & 0.6724 & -2.55263 & 1 \\
\hline 34 & 0 & 0.5411 & 0.8063 & 0.637 & 0.9791 & -4.53513 & 0 \\
\hline 35 & 1.4822 & 1.0097 & 1.2966 & 0.9218 & 1.0961 & -2.38326 & 1 \\
\hline 36 & 0.8863 & 0.9016 & 0.7196 & 0.9743 & 3.1312 & -3.05839 & 0 \\
\hline
\end{tabular}

The second objective was to determine the financial soundness of non-banking firms listed in Nairobi securities exchange. To ascertain whether non-banking firms were in financial distress, Altman's ZScore was applied. The Altman Z-Score results on firms analysed are presented in table 2. 
INTERNATIONAL JOURNAL OF ACADEMIC RESEARCH IN ACCOUNTING, FINANCE AND MANAGEMENT SCIENCES

Vol. 11, No. 1, 2021, E-ISSN: 2225-8329 @ 2021 HRMARS

Table 2: Altman Z-Score Results for Financial Status

\begin{tabular}{|c|c|c|c|c|c|c|c|}
\hline Firms & $\mathbf{X 1}$ & $\times 2$ & $\mathbf{X 3}$ & $\mathrm{X} 4$ & $\times 5$ & Z-Score & Status \\
\hline 1 & 0.0638 & 0.1081 & -0.0813 & 4.3522 & 0.0513 & 2.62223 & Grey \\
\hline 2 & -0.1658 & 0.215 & 0.2097 & 2.0763 & 0.202 & 2.24183 & Grey \\
\hline 3 & 0.2406 & 0.617 & 0.0314 & 2.7593 & 0.2721 & 3.18382 & Financially Sound \\
\hline 4 & -0.2164 & 0.0894 & 0.0325 & 0.0147 & 0.3428 & 0.32435 & Financial Distress \\
\hline 5 & 0.2619 & -0.4024 & -0.4265 & 1.8192 & 0.7672 & 0.20219 & Financial Distress \\
\hline 6 & 0.3633 & 0.744 & 0.14 & 5.718 & 0.4467 & 5.81706 & Financially Sound \\
\hline 7 & 0.5219 & 0.7143 & 0.025 & 20.7473 & 0.3863 & 14.5435 & Financially Sound \\
\hline 8 & 0.1298 & 0.1235 & -0.0014 & 6.752 & 0.1085 & 4.48374 & Financially Sound \\
\hline 9 & -0.5139 & 0.3174 & 0.0033 & 0.4786 & 0.0128 & 0.13853 & Financial Distress \\
\hline 10 & 0.0492 & -0.9396 & -0.0293 & 1.071 & 0.043 & -0.6675 & Financial Distress \\
\hline 11 & -0.221 & -0.414 & -0.007 & 0.1114 & 0.5398 & -0.2613 & Financial Distress \\
\hline 12 & 0.1285 & 0.0593 & 0.0678 & 1.8752 & 0.1336 & 1.71968 & Financial Distress \\
\hline 13 & -0.0663 & -0.8097 & -0.1795 & 0.5243 & 0.6756 & -0.8153 & Financial Distress \\
\hline 14 & -0.3027 & 0.1342 & -0.1187 & 0.7067 & 0.8362 & 0.69315 & Financial Distress \\
\hline 15 & 0.3138 & 0.5928 & 0.1184 & 0.9012 & 0.6857 & 2.82362 & Financial Distress \\
\hline 16 & 0.1632 & 0.2087 & 0.132 & 1.0357 & 0.5674 & 2.11244 & Grey \\
\hline 17 & 0.02 & 0.2158 & 0.0381 & 0.1444 & 0.1145 & 0.65299 & Financial Distress \\
\hline 18 & 0.0101 & 0.0556 & 0.6631 & 13.9302 & 0.6674 & 11.3037 & Financially Sound \\
\hline 19 & 0.2281 & 0.0833 & 0.1119 & 10.2022 & 0.1288 & 7.00973 & Financially Sound \\
\hline 20 & 0.3123 & 0.387 & 0.0823 & 0.3666 & 0.2981 & 1.70621 & Financial Distress \\
\hline 21 & -0.0475 & 0.1339 & 0.0571 & 1.0668 & 0.0749 & 1.03387 & Financial Distress \\
\hline 22 & 0.081 & 0.2148 & 0.145 & 0.5083 & 0.699 & 1.8804 & Grey \\
\hline 23 & 0.3394 & 0.3312 & 0.1057 & 0.3108 & 3.8331 & 5.23935 & Financially Sound \\
\hline 24 & 0.2571 & 0.653 & 0.0373 & 2.3778 & 0.5034 & 3.27589 & Financially Sound \\
\hline 25 & 0.389 & 0.3278 & 0.039 & 17.6768 & 0.2699 & 11.9304 & Financially Sound \\
\hline 26 & 0.1258 & 0.3328 & 0.0437 & 1.7277 & 0.6628 & 2.46051 & Grey \\
\hline 27 & 0.127 & 0.2135 & 0.3109 & 4.4802 & 2.1622 & 6.32759 & Financially Sound \\
\hline 28 & 0.2406 & 0.7926 & 0.1177 & 7.8002 & 0.1882 & 6.65509 & Financially Sound \\
\hline 29 & 0.0635 & 0.3752 & 0.0249 & 0.2055 & 0.0311 & 0.83805 & Financial Distress \\
\hline 30 & -0.0503 & 0.2557 & 0.0559 & 0.7454 & 1.4497 & 2.37903 & Grey \\
\hline 31 & 0.3065 & 0.3413 & 0.0675 & 0.5112 & 1.681 & 3.05609 & Financially Sound \\
\hline 32 & -0.044 & 0.383 & 0.4773 & 19.1395 & 1.2356 & 14.7778 & Financially Sound \\
\hline 33 & 0.0751 & 0.0405 & 0.0452 & 8.7806 & 0.0912 & 5.65554 & Financially Sound \\
\hline 34 & -2.7671 & -3.5418 & -0.3042 & 0.1121 & 0.022 & -9.1936 & Financial Distress \\
\hline 35 & 0.2597 & 0.3184 & 0.4027 & 0.0032 & 1.1144 & 3.20263 & Financially Sound \\
\hline 36 & 0.0829 & 0.1829 & 0.0727 & 0.15 & 1.0629 & 1.74835 & Financial Distress \\
\hline
\end{tabular}

NB: Names of institutions have been omitted from the article to avoid panic and mass sale of stock that may affect the economy. 
INTERNATIONAL JOURNAL OF ACADEMIC RESEARCH IN ACCOUNTING, FINANCE AND

MANAGEMENT SCIENCES

Vol. 11, No. 1, 2021, E-ISSN: 2225-8329 @ 2021 HRMARS

The results of Altman Z-Score presented in table 2 shows that 15 firms were financially sound translating to $41.7 \%$. An equal number of 15 firms of the analysed firms were found to be in financial distress while 6 firms translating 16.6\% were in grey area meaning that the firms may improve financially or fall in financial distress as per categorization by Mavengere (2015).

\section{Conclusion and Discussion}

The first research objective was to establish whether the non-banking firms listed in Nairobi Securities Exchange were involved in earning manipulations. The research findings show that a majority of nonbanking firms analysed (58.3\%) were not involved in earning manipulations, however a worrying substantial number (41.7\%) were involved in earning manipulations. It was therefore concluded that majority of firms did not engage in earning manipulation, however a large proportion of firms analysed were practising earning manipulation. The study results have similar findings to those of Pereira and Alves (2017) who found that non-financial firms in Portugal practised earning management even after adopting the use of international financial reporting standards and international accounting standards. The study by Ramírez-Orellana et al. (2017) also found that a food company (Pescanova) was involved in financial earning manipulations one year prior to the company facing financial difficulties, this means earning manipulations is prevalent in almost all sectors of the economy. The earning manipulations as per Beneish model detected in the analysis is contrary to the results obtained by Mehta and Bhavani (2017), in analysis of financial statements of Toshiba as a company. The results indicated that there was no financial statement fraud through earning manipulation. The manipulations of earnings may be due to lapses in the laws and accounting standards that the accountants manipulate with the knowledge and assistance of the management. The other reasons may be to conceal the real financial position of the firm and soar up investors' confidence. Lastly this trend of earning manipulation may be amplified by the need to avoid tax, therefore management try to reduce the tax liability by reducing the taxable income.

The second research objective was to determine the financial soundness of non-banking firms listed in Nairobi Securities Exchange. The Altman's Z-Score model was applied to test the financial soundness of these firms based on their latest audited financial statements. The research findings pointed out that $41.7 \%$ of the firms analysed were financially sound, $16.6 \%$ of the analysed firms were categorised as grey which means they are not yet financially distressed or financially stable but they can fall in either of the categories and the remaining 15 firms also accounting for $41.7 \%$ of the total analysed firms were categorised as financially distressed. The study therefore concluded that some listed firms in Kenya's securities exchange market are not financially sound. Mehta and Bhavani (2017) indicated that Altman Z-Score can predict bankruptcy with 95\% accuracy level, based on this assertion it is further concluded that there is a 0.95 probability of all firms categorised as distressed financially to be declared bankrupt unless there is quick intervention to rescue them financially. The study findings concur with findings of Mehta and Bhavani (2017) that found that Toshiba was in financial distress and also a study undertaken by Mavengere (2015) that found that Z manufacturing company in Zimbabwe was also financially distressed. The Altman Z-Score has been used to detect fraud in financial statements (Mehta \& Bhavani, 2017). Therefore the financially distressed firms and those categorised as grey may be involved in fraud or corruption. Alternatively they may be involved in mismanagement of financial resources by those who are entrusted in safeguarding the investors' resources for their personal gains. 
INTERNATIONAL JOURNAL OF ACADEMIC RESEARCH IN ACCOUNTING, FINANCE AND MANAGEMENT SCIENCES

Vol. 11, No. 1, 2021, E-ISSN: $2225-8329$ @ 2021 HRMARS

\section{Recommendations}

The research findings showed that $41.7 \%$ of firms analysed were practising earning manipulations. Earning manipulations mostly is done to hoodwink authority for tax purposes or the investors by presenting wrong financial reports that benefit the perpetrators. The practise of earning manipulation is mostly not beneficial to the owners of the businesses but the managers who act as agents for shareholders. Therefore it is recommended that the government and other regulating agents involved on how integrated financial reports are prepared should add an additional requirement to the auditors that; before the auditors certify the financial as reflecting true and fair view they should ensure that there are no acts of earning manipulations by calculating the necessary ratios. The ratios computed will assist the auditors in scrutinizing the financial statements further before ascertaining their soundness hence providing the investors and owners of the businesses with actual financial status of the firm. Ratios computed by auditor will deter the management from manipulating accounts in the future to avoid being exposed through audit reports. It is further recommended that the perpetrators of fraudulent manipulations are held personally accountable for their act by being convicted and jailed or be forced to restitute the defrauded firm or both. This action will act as deterrent as the perpetrators will know that there is a price to pay for their action. If a person is convicted for financial fraud and punished for it, he will be hesitant to engage in such acts in the future. Other managers and employees will also learn that there will be a heavy price to pay in case one engages in financial manipulation and hence they will ensure that the financial status of the firm is reported correctly.

In case of financial distress of the firm, it was found that $41.7 \%$ of firms were in financial distress and $16.6 \%$ of firms were in grey area meaning that the firms may fall into financial distress. It is therefore recommended that the owners of the firms may raise more capital if the distress is due to hard economic times. Further investment in firms will assist the firms overcome the hard economic period and hence future prospect expansion and profitability in better economic period. However if it is found that; management negligence, greed and shear mismanagement contributed to the distress, the managers must be disciplined and prosecuted where criminal culpability is proved. The prosecution of the managers that are culpable will ensure that the remaining managers or future managers entrusted with finances safeguard these resources against mismanagement and misuse to benefit the owners of the firms. The firms that have government control or interest like Kenya power and lighting company and Kenya airways which have been found to be financially distressed in the analysis, they may seek government bailout. It is recommended that the government provide bailout to these firms as they offer vital services to the populace. However, the bailout should be provided after a thorough analysis and scrutiny of the cause of distress. The bailout will ensure continuity of essential service delivery to the population as failure to provide such financial assistance may lead to economic failure.

\section{Acknowledgement}

The research was financed by National Research Fund

\section{References}

Abbadi, S., Hijazi, Q., \& Al-Rahahleh, A. (2016). Corporate Governance Quality and Earnings Management: Evidence from Jordan. Australasian Accounting, Business and Finance Journal, 10(2), 54-75. https://doi.org/10.14453/aabfj.v10i2.4 
INTERNATIONAL JOURNAL OF ACADEMIC RESEARCH IN ACCOUNTING, FINANCE AND MANAGEMENT SCIENCES

Vol. 11, No. 1, 2021, E-ISSN: 2225-8329 @ 2021 HRMARS

Ahmed, T., \& Naima, J. (2016). Detection and analysis of probable earnings manipulation by firms in a developing country. Asian Journal of Business and Accounting, 9(1), 59-81.

Ali, U., Noor, M., Khurshid, M. K., \& Mahmood, A. (2015). Impact of Firm Size on Earnings Management: A Study of Textile Sector of Pakistan. SSRN Electronic Journal, 7(28), 47-56. https://doi.org/10.2139/ssrn.2698317

Feruleva, N., \& Maria, S. (2017). Detecting financial statements fraud: the evidence from Russia. Journal of Corporate Finance Research, 12(2), 32-35.

Haque, A., Mughal, A., \& Zahid, Z. (2016). Earning Management and the Role of Accounting Conservatism at Firm Level. International Journal of Economics and Finance, 8(2), 197-205. https://doi.org/10.5539/ijef.v8n2p197

Iraya, C., Mwangi, M., \& Muchoki, G. W. (2015). the Effect of Corporate Governance Practices on Earnings Management of Companies Listed At the Nairobi Securities Exchange. European Scientific Journal, 11(1), 169-178. https://doi.org/10.19044/esj.2015.v11n1p\%p

Ismail, N. I., Zakaria, N. B., \& Sata, F. H. A. (2015). Auditors Roles Towards the Practice of Earnings Manipulation among the Malaysian Public Firms. Procedia Economics and Finance, 28(April), 145-150. https://doi.org/10.1016/s2212-5671(15)01093-x

Lu, Y. (2017). Research on the Effect on Tax Burden of Earning Management Based on Lipschitz Theory. International Conference on Culture, Education and Financial Development of Modern Society, 103(Iccese), 692-696. https://doi.org/10.2991/iccese-17.2017.175

Mahama, M. (2015). Detecting corporate fraud and financial distress using the Atman and Beneish models. International Journal of Economics, Commerce and Management, 3(1), 1-18.

Mavengere, K. (2015). Predicting corporate bankruptcy and earnings manipulation using the Altman $Z$-score and Beneish $M$ score. The case ofZ manufacturing firm in Zimbabwe. Author Details: Kudakwashe MAVENGERE- Lupane State University,Department of Accounting and Finance. 10, 8-14.

Mehta, A., \& Bhavani, G. (2017). Application of Forensic Tools to Detect fraud: The Case of Toshiba. Journal of Forensic and Investigative Accounting, 9(1), 1188-1197. https://doi.org/10.1111/j.1469-7610.2010.02280.x

Muda, I., Maulana, W., Siregar, H. S., \& Indra, N. (2018). The analysis of effects of good corporate governance on earnings management in Indonesia with panel data approach. Iranian Economic Review, 22(2), 599-625.

Nikoomaram, H., Arabahmadi, F., \& Arabahmadi, A. (2016). The Relationship between earning management and capital structure. International Journal of Finance and Managerial Accounting, 1(1), 51-56.

Omar, N., Koya, R. K., Sanusi, Z. M., \& Shafie, N. A. (2014). Financial Statement Fraud: A Case Examination Using Beneish Model and Ratio Analysis. International Journal of Trade, Economics and Finance, 5(2), 184-186. https://doi.org/10.7763/ijtef.2014.v5.367

Paolone, F., \& Magazzino, C. (2014). Earnings Manipulation Among the Main Industrial Sectors. Evidence from Italy. Economia Aziendale Online, 5(4), 253-261. https://doi.org/10.4485/ea203-5498.005.0022

Pereira, A., \& Alves, M. D. C. G. (2017). La manipulación contable y el Reglamento Europeo 1606/2002: evidencias de empresas portuguesas no financieras que cotizan en Euronext. Revista de Contabilidad, 20(2), 107-117. https://doi.org/10.1016/j.rcsar.2017.05.002

Ramírez-Orellana, A., Martínez-Romero, M. J., \& Mariño-Garrido, T. (2017). Measuring fraud and 
INTERNATIONAL JOURNAL OF ACADEMIC RESEARCH IN ACCOUNTING, FINANCE AND

\section{MANAGEMENT SCIENCES}

Vol. 11, No. 1, 2021, E-ISSN: 2225-8329 (c) 2021 HRMARS

earnings management by a case of study: Evidence from an international family business.

European Journal of Family Business, 7(1-2), 41-53.

https://doi.org/10.1016/j.ejfb.2017.10.001

Roxas, M. L. (2011). Financial Statement Fraud Detection Using Ratio and Digital Analysis. Journal of Leadership, Accountability and Ethics, 8(4), 56-66.

Sari, R. P., \& Sari, R. P. (2019). Study of Earning Management and Audit Quality in Indonesi. Journal of Economics, Business, and Government Challenges, 1(2), 79-88. https://doi.org/10.33005/ebgc.v1i2.23

Shahzad, A. (2016). Detecting Earning Management and Earning Manipulation in BRIC Countries; a Panel Data Analysis for Post Global Financial Crisis Period. International Journal of Accounting Research, 4(1), 1-10. https://doi.org/10.4172/2472-114x.1000134

Tarjo, \& Herawati, N. (2015). Application of Beneish M-Score Models and Data Mining to Detect Financial Fraud. 2nd Global Conference on Business and Social Science-2015, GCBSS-2015, 1718 September 2015, Bali, Indonesia, 211(September), 924-930.

https://doi.org/10.1016/j.sbspro.2015.11.122 